\title{
Preliminary Study of Atmospheric Methane Emissions in a lentic systems
}

\author{
Lia Braz, Willian José Ferreira, Plínio Carlos Alvalá (CCST - INPE)
}

Copyright 2011, SBGf - Sociedade Brasileira de Geofísica

This paper was prepared for presentation during the $12^{\text {th }}$ International Congress of the Brazilian Geophysical Society held in Rio de Janeiro, Brazil, August 15-18, 2011.

Contents of this paper were reviewed by the Technical Committee of the $12^{\text {th }}$ International Congress of the Brazilian Geophysical Society and do not necessarily represent any position of the SBGf, its officers or members. Electronic reproduction or of the Brazilian Geophysical Society is prohibited.

\section{Abstract}

The decaying organic matter releases, among other gases, methane $(\mathrm{CH} 4)$, composed of semi-opaque to infrared radiation has an important role in the greenhouse. The knowledge of how the lentic systems emit gases from the anaerobic decomposition of nonlignified material, primarily composed of herbaceous plants and areas of peeling macrophytes has been highlighted in several studies. This paper presents the results of a preliminary test to work on the emission of greenhouse gases in reservoirs on the methane produced in one of the ponds for water supply INPE - National Institute for Space Research, Cachoeira Paulista / SP. To determine the flow of methane was carried out a campaign in December 2010 and the gas flow determined using the static chamber technique. The environmental parameters measured were the temperature of air and water, $\mathrm{pH}$, redox potential, conductivity, dissolved oxygen and total dissolved solids. The overall average of valid flows was $59.1 \pm 91.98 \mathrm{mgCH} 4 / \mathrm{m} 2 / \mathrm{dia}$ and analysis of the environmental parameters indicates that the methane concentration was high in environments with a $\mathrm{pH}$ lower than 4 and lower levels of dissolved oxygen in water.

\section{Introduction}

Methane is the most abundant hydrocarbon in the atmosphere. The mixing ratio of atmospheric methane has doubled since the Industrial Revolution, currently around 1800 ppbv (parts per billion by volume). Only in recent years that gas emissions grew by about $1 \%$ per year (Holmes, 1999 apud Pellizari et al., 2007) and human intervention on natural processes have acted on the stability of climate and heat balance of the planet.

The emissions of this gas can be natural or manmade, where natural sources are composed of wetlands, colonies of termites, ruminants, oceans and hydrates, while the sources of human emissions are from agriculture and waste dump, and both affected by several factors, including energy use, population distribution, agricultural practices and the climate itself.

Preliminary data on methane emissions in Brazil were made in the Brazilian inventory of anthropogenic emissions and removals of greenhouse gases (BRAZIL, 2009). According to the report, about $70 \%$ of Brazil's emissions come from agriculture and livestock, with livestock making up most of that percentage issuer. However, wetlands that contribute to methane emissions to the atmosphere account for about $20 \%$ of global emissions (WUEBBLES; Hayhoe, 2002). Studies Melack et al. (2004) and Marani (2007) have a contribution to the river system may present due to the accumulation of organic matter and its degradation in sites of low flow of rivers and wetlands in the country, suggesting that natural emissions of methane on the order of $2 \mathrm{Tg} /$ year.

In this work we measured the methane emissions in lentic water bodies, which refer to systems where it shows the still water, slow moving or stagnant, and evaluated the influence of environmental variables that can affect the emission of gas.

\section{Method}

Collections were made by the method of atmospheric static camera in the water bodies and the samples analyzed by gas chromatography with FID detector. The flow of methane was determined by the method described by Khalil et al. (1998).

To measure the contribution of flow at each sampling point were measured parameters in the water column, using a multiparameter probe water quality brand Horiba, model U-51. We measured $\mathrm{pH}$, redox potential, electrical conductivity, total dissolved solids, temperature of air and water. From these data could be observed variability and possible links between the methane fluxes and environmental variables measured.

\section{Results}

The pond where the collection was made is located at the National Institute for Space Research, Cachoeira Paulista, centered on the geographic coordinates $22^{\circ}$ $41^{\prime} \mathrm{S}$ and $44^{\circ} 59^{\prime} \mathrm{W}$. This pond is used for water supply of INPE. It has a perimeter of about $827 \mathrm{~m}$. Measurements taken in December 2010.

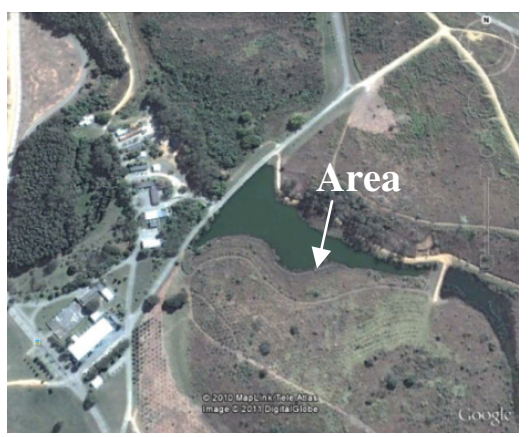

Fig.1 - Aerial view of the pond INPE - Cachoeira Paulista. Source: Google 2008 
As described by Khalil et al. (1998), the gas flow was determined by the variation of methane inside the camera positioned over the pond over time. To increase the reliability of the determination of flows in each collection point were used three cameras and thus each flow was determined by the set of four syringes obtained by each chamber. At every point samples were collected to validate the air flow obtained.

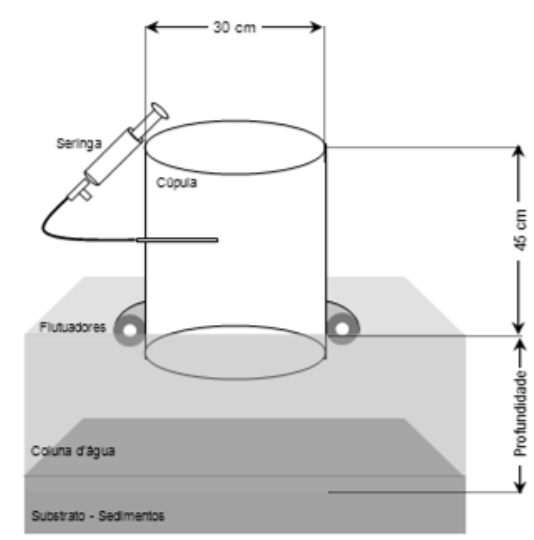

Fig.2 - Set to air collected with the static camera and syringe. Source: Adapted from Silva (2010)

We collected 65 samples resulted in 14 valid fluxes, of which 3 were classified as 11 ebullitive emission and diffusion.

The bubble flux variation is present between 78.99 to $269.69 \mathrm{mgCH} 4 / \mathrm{m} 2 / \mathrm{dia}$, with average flow of $206.1 \pm$ $110.1 \mathrm{mgCH} 4 / \mathrm{m} 2 / \mathrm{dia}$ and a median of 53.4 $\mathrm{mgCH} 4 / \mathrm{m} 2 /$ dia. Figure 3 (a) is shown graphically a bubble flux obtained in this campaign, despite the value of the square of correlation coefficient obtained was 0.91 , when analyzing the curve is clear the presence of a bubble between minutes 10 and 15 . As the occurrence of the bubble is not in the initial minutes, so there is no interference of the disturbance when placing the dome in the pond, and the next minute this initial concentration of 1980 ppbv ambient air. Making valid and ebullitive emission stream.

The largest number of cases occurred in a diffusive, and its variation range between 1.98 to $56.94 \mathrm{mgCH} 4 / \mathrm{m} 2 / \mathrm{dia}$, with average flow of $18.9 \pm 17.9 \mathrm{mgCH} 4 / \mathrm{m} 2 / \mathrm{dia}$ and a median of $94,4 \mathrm{mgCH} 4 / \mathrm{m} 2 / \mathrm{dia}$. Figure 3 (b) is shown graphically a diffusive flux obtained in this campaign, where the first validation criterion, the square of the correlation coefficient obtained was 0.99 .

As can be seen in the graph concentration (ppbv) of methane obtained from the linear regression is around 1850 ppbv, a value similar to that obtained by ambient air of 1879 ppbv. Having met the two criteria is considered valid flow and diffusive. The overall average of 14 streams was $59.1 \pm 91.98 \mathrm{mgCH} 4 / \mathrm{m} 2 / \mathrm{dia}$, with a median of $155.7 \mathrm{mgCH} 4 / \mathrm{m} 2 / \mathrm{dia}$.
Table 1 is presented the mean, standard deviation and the range of variation of environmental parameters measured at the surface of the pond located at INPE.
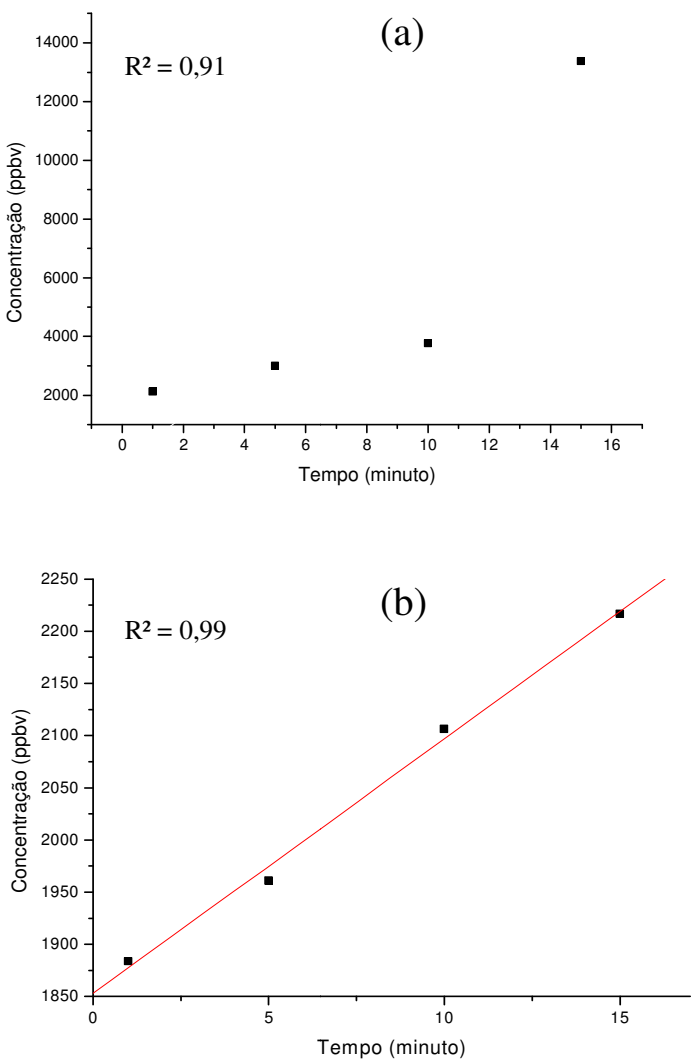

Fig.3 - bubble flux (a) and DF (b) obtained in the campaign.

Below, in Table 1 shows the variations of environmental parameters measured.

Table 1 - Mean, standard deviation and range of environmental parameters.

\begin{tabular}{cccc}
\hline \hline $\begin{array}{c}\text { Environmental } \\
\text { Parameters }\end{array}$ & Range & Average & STD \\
\hline Air Temperature $\left({ }^{\circ} \mathrm{C}\right)$ & $34,3-38,0$ & 35,62 & 1,3582 \\
\hline $\begin{array}{c}\text { Water Temperature } \\
\left({ }^{\circ} \mathrm{C}\right)\end{array}$ & $28,3-29,4$ & 28,67 & 0,3843 \\
\hline $\mathrm{pH}$ & $2,7-6,7$ & 4,23 & 1,5109 \\
\hline ORP $(\mathrm{mV})$ & $96,0-338,0$ & 248,60 & 90,0276 \\
\hline $\begin{array}{c}\text { Electrical } \\
\text { conductivity }(\mathrm{S} / \mathrm{m})\end{array}$ & $0,013-0,014$ & 0,01 & 0,0005 \\
\hline $\begin{array}{c}\text { Dissolved oxygen } \\
(\mathrm{mg} / \mathrm{l})\end{array}$ & $7,62-9,27$ & 8,28 & 0,5770 \\
\hline TSD (g/t) & $0,008-0,009$ & 0,01 & 0,0004 \\
\hline
\end{tabular}


The average values obtained in this work is smaller than those found by Silva (2010) in the Pantanal (163.8 \pm $343.2 \mathrm{mgCH} 4 \mathrm{~m}-2 \mathrm{~d}-1$, with a median of $39.0 \mathrm{mgCH} 4 \mathrm{~m}-2 \mathrm{~d}-$ 1), as well as Marani (2007) in the Pantanal (116.8 \pm $275.8 \mathrm{mgCH} 4 \mathrm{~m}-2 \mathrm{~d}-1$, with a median of $11.1 \mathrm{mgCH} 4 \mathrm{~m}-2 \mathrm{~d}-$ 1). Many of the Pantanal wetlands include forested areas near rivers or on the plains. In these areas the rates are relatively high primary productivity and decomposition rates. What justifies the difference in values of the fluxes obtained in the study area of this work, you do not understand the forest.

\section{Conclusions}

The main feature of a lentic system is the high solubilization capacity for organic compounds, low in dissolved salts, high density and viscosity of water, sediment capacity, "seiches" internal, temperature and underwater radiation.

What determines the quality of water of a lentic system is both natural phenomena such as human action (Esteves, 1998). In this system three factors are particularly important in the emission of greenhouse gases: the amount of organic matter in water depth and weather conditions (SVENSSON, 2005).

Methane production by the decomposition of organic matter has an important role in local and global cycle of carbon and represents about $80 \%$ of the methane entering the atmosphere (Manahan, 1994).

The flow of methane found in this pond in Cachoeira Paulista indicated that the strong relationship between production / methane concentration and $\mathrm{pH}$ factor when it is less than 4 and low levels of dissolved oxygen.

\section{Acknowledgments}

CNPq for the scholarship by the Scholarship Program for Undergraduate Research at the National Institute for Space Research from the first author.

\section{References}

BRASIL. Ministério da Ciência e Tecnologia. Inventário Brasileiro das Emissões e Remoções Antrópicas de Gases de Efeito Estufa: Informações gerais e valores preliminares. Brasília, 2009, 16p.

ESTEVES, F. A. Fundamentos de Limnologia. Rio de Janeiro: Interciência, 1998. 602 p. ISBN 85-7193-008-2.

KHALIL, M.A.K.; RASMUSSEN, R.A.; SHEARER, M.; DALLUGE, R.; REN, L.; DUAN, C.L., Factors affecting methane emissions from rice fields. J. Geophys. Res., v. 103, n. D19, p. 25219-25231, 1998.

MANAHAN, S E. Environmental Chemistry. 6. ed. Boca Raton (Florida - USA): Lewis Publishers, 1994.612 p.

MARANI, L. Estudo da emissão de metano no Pantanal Sul Matogrossense. 2007. 108p. Tese (Doutorado em
Geofísica Espacial) - Instituto Nacional de Pesquisas Espaciais. Orientador: Plínio Carlos Alvalá.

MELACK, J. M.; HESS, L. L.; GASTIL, M.; FORSBERG, B. R.; HAMILTON, S. K.; LIMA, I. B. T.; NOVO, E. M. L. M. Regionalization of methane emissions in the Amazon basin with microwave remote sensing. Global Change Biol., v.10, p. 530-544, 2004.

PELLIZARI, V. H.; NAKAYAMA, C. R.; ARAUJO, A. C. V.; LIOTTI R. G.; VAZOLLER, R. F. Metano, Mudanças Climáticas Globais e a Microbiologia. Microbiologia In Foco, 2007, p.4-9.

SILVA, M. G. Variação interanual e análise da influência de parâmetros ambientais na emissão de metano no Pantanal. 2010. 99p. Dissertação (Mestrado em Geofísica Espacial) - Instituto Nacional de Pesquisas Espaciais. Orientador: Plínio Carlos Alvalá.

SVENSSON, B. Greenhouse gas emission from hydroelectric reservoirs: a global perspective. In: SEMINAR ON GREENHOUSE FLUXES FROM HYDRO RESERVOIR AND WORKSHOP ON MODELING GREENHOUSE GAS EMISSIONS FROM RESERVOIR AT WATERSHED LEVEL, 2005, Rio de Janeiro. Proceedings...: Rio de Janeiro: ELETROBRAS, COPPE/UFRJ.

WUEBBLES, D. J.; HAYLOE, K. Atmospheric methane and global change. Earth-Science Reviews, v.57, 2002, p.177-210. 